\title{
Peningkatan Kualitas Pembelajaran Jarak Jauh (PJJ) Berbasis FOCQIPOTU
}

\author{
Hamzah Sa'ban Saragih ${ }^{1}$, Risna Mira Bella Saragih ${ }^{2}$, Khoiruddin Matondang $^{3}$ \\ 1,2,3 Program Studi Pendidikan Matematika, Fakultas Keguruan dan Ilmu Pendidikan, Universitas Al Washliyah Medan, \\ Jl. Sisingamangaraja No. 10, Medan, Indonesia \\ hamzahsaragih322@gmail.com
}

\begin{abstract}
Distance learning mathematics subjects is one of the problems for junior high school students, one solution to improve the quality of distance learning mathematics with FOCQIPOTU. The purpose of this study is to analyze whether FOCQIPOTU can improve the quality of distance learning mathematics in junior high schools, (2) how students' activities during learning use FOCQIPOTU. This type of research is a Quasi Experiment with Pretest Posttest Control Group Design. The research population was all seventh' grade students of SMP IT Indah Medan. Group random sampling technique (cluster random sampling). The instrument used was a test description of algebraic material and observation sheets. The results showed: 1) There were the differences between students who took FOCQIPOTU learning and students who took conventional learning, the 2-way significance value (t-tailed) $0.000<0.05$. The average category of student activity in FOCQIPOTU learning is good (3.86) with the activity steps carried out by students during FOCQIPOTU learning students join whatsapp groups, students join Classroom, students follow learning with Google Form guides, understand material through youtube, ask things you don't know, do practice questions on Quizizz.
\end{abstract}

Keywords: Learning, Distance, FOCQIPOTU

\begin{abstract}
Abstrak
Pembelajaran Jarak Jauh mata pelajaran matematika menjadi salah satu masalah bagi siswa SMP, salah satu solusi meningkatkan kualitas pembelajaran jarak jauh matematika dengan FOCQIPOTU. FOCQIPOTU adalah pembelajaran jarak jauh pelajaran matematika di SMP yang mengkombinasikan Google Formulir, Classroom, Quiziz, Powerpoint dan Youtube dalam sintaks pembelajaran. Tujuan dari penelitian ini adalah menganalisa apakah FOCQIPOTU dapat meningkatkan kualitas pembelajaran jarak jauh matematika di SMP, (2) bagaimana aktivitas siswa selama pembelajaran menggunakan FOCQIPOTU. Jenis penelitian ini adalah Quasi Eksperimen dengan Pretest-Posttest Control Group Design. Populasi penelitian adalah seluruh siswa kelas VII SMP IT Indah. Teknik pengambilan sampel kelompok secara acak (cluster random sampling). Instrumen yang digunakan tes uraian materi aljabar dan lembar observasi. Hasil penelitian menunjukkan: 1) Terdapat perbedaan peningkatan antara siswa yang mengikuti pembelajaran FOCQIPOTU dengan siswa yang mengikuti pembelajaran konvensional, nilai signifikansi 2 arah (t-tailed) $0.000<0.05$. Rata-rata kategori aktivitas siswa dalam pembelajaran FOCQIPOTU baik $(3,86)$ dengan langkah-langkah aktivitas yang dilakukan siswa selama pembelajaran FOCQIPOTU siswa bergabung dalam whatsapp grup, siswa bergabung dalam Classroom, siswa mengikuti pembelajaran dengan guide Google Form, memahami materi melalui youtube, menanyakan hal-hal yang belum diketahui, mengerjakan latihan soal di Quizizz.
\end{abstract}

Kata kunci: Pembelajaran, Jarak Jauh, FOCQIPOTU

Copyright (c) 2021 Hamzah Sa'ban Saragih, Risna Mira Bella Saragih, Khoiruddin Matondang $\triangle$ Corresponding author: Risna Mira Bella Saragih

Email Address: risnamirabellasaragih@gmail.com (Jl. Sisingamangaraja No. 10, Medan, Indonesia)

Received 06 September 2021, Accepted 23 October 2021, Published 28 December 2021

\section{PENDAHULUAN}

Belajar matematika dengan konsep PJJ merupakan hal yang baru dan menimbulkan masalah tersendiri bagi siswa. Masalah kesulitan siswa yang sering terjadi selama PJJ, siswa belum terbiasa dalam melaksanakan kebutuhan belajar online dirumah, masih ada siswa yang menyerah mengerjakan tugas e-learning matematika ketika terdapat kesulitan (Utami \& Cahyono, 2020). Siswa merasaa cemas karena kurangnya interaksi dan komunikasi dengan teman-temannya. Kurangnya kegiatan belajar berkelompok menjadi faktor kurangnya motivasi siswa dalam belajar (Yustika et 
Peningkatan Kualitas Pembelajaran Jarak Jauh (PJJ) Berbasis FOCQIPOTU, Hamzah Sa'ban Saragih, Risna Mira Bella Saragih, Khoiruddin Matondang

al., 2019).

Keberhasilan pembelajaran jarak jauh sangat tergantung pada guru, kesiapan guru dalam mempersiapkan PJJ, tanggung jawab untuk mengayomi siswa, penggunaan aplikasi IT dalam pembelajaran, pemilihan media pembelajaran yang sesuai dengan PJJ. Guru harus mampu mendesain pembelajaran yang menarik dan tidak menimbulkan rasa bosan bagi siswa. Guru dituntut untuk mampu memanfaatkan aplikasi/platform yang tersedia untuk meningkatkan efisiensi dan efektivitas pembelajaran (Fajriana* \& Safriana, 2021). Guru yang siap melaksanakan pembelajaran daring hanya $14.78 \%$, selebihnya $85,22 \%$ belum siap melaksanakan pembelajaran daring (Prabowo et al., 2020).

Dari beberapa masalah yang muncul selama PJJ perlu dicarikan solusi yang mampu mengakomodir peningkatan kualitas PJJ. Solusi yang ditawarkan dengan melaksanakan pembelajaran berbasis FOCQIPOTU. Adapun FOCQIPOTU adalah pembelajaran jarak jauh pelajaran matematika di SMP yang mengkombinasikan Google Form, Classroom, Quiziz, Powerpoint dan Youtube. Salah satu hal yang perlu disiapkan guru agar bisa bersaing di era industri 4.0 adalah guru mahir dalam menerapkan teknologi informasi dalam pembelajaran (Santoso et al., 2020). Aplikasi tersebut sangat sesuai dengan kebutuhan PJJ dan sesuai dengan kebutuhan revolusi pembelajaran 4.0.

Google formulir adalah sebuah aplikasi untuk membuat sebuah survei dan kuesioner yang dikembang (Iqbal et al., 2018). Google form salah satu media yang digunakan dalam proses pembelajaran yang berkaitan dengan mata pelajaran dan penilaian. Disamping itu Google formulir memiliki kemudahan dan efektivitas dalam mendukung pembelajaran yang berbasis internet.

Google Form dapat diakses dengan mudah dan secara otomatis soal bisa diatur secara acak. Untuk soal pilihan ganda dan isian singkat, Google formulir dapat mengoreksi jawaban secara otomatis dan peserta didik dapat mengetahui nilai hasil evaluasi pembelajaran setelah selesai mengerjakan. Google formulir akan secara otomatis menyimpan hasil pekerjaan siswa dan guru dapat mengunduh dalam bentuk Excel. Tampilan Google Form menarik, menyediakan fasilitas memasukkan dan menggunakan foto atau logo sendiri (Purwati \& Nugroho, 2018). Memiliki banyak template yang membuat kuis dan kuesioner online tersebut semakin menarik dan berwarna. Memiliki berbagai jenis tes yang bebas dipilih. Aplikasi ini menyediakan fasilitas pilihan tes yang bebas digunakan sesuai dengan keperluan pengguna (Husein, 2016).

Google classroom adalah aplikasi media pembelajaran online. Google classroom dapat memudahkan guru dalam membuat, membagikan serta mengelompokkan setiap tugas tanpa menggunakan kertas lagi (Sudarman et al., 2021). Google classroom membantu guru dan siswa menemukan jalan keluar atas permasalahan dalam pembelajaran yang dilakukan secara tatap muka (Asyura \& Dewi, 2020). Penggunaan Google classroom akan membuat pembelajaran menjadi lebih efektif, siswa nantinya dapat belajar, menyimak, membaca, mengirim tugas, dari jarak jauh (Soni et al., 2018) .Ada tiga piliha menu utama pada google classroomyaitu Stream, Classwork dan People. Stream adalah fasilitas untuk membuat pengumuman, mendiskusikan materi, Classwork dapat 
digunakan guru untuk membuat materi, soal latihan, quiz. People dapat melihat anggota dan tim pengajar.

Quiziz merupakan aplikasi pendidikan berbasis game yang interaktif dan menyenangkan (Purba, 2019). Quiziz memiliki karakteristik permainan seperti avatar, meme musik yang bisa menghibur siswa dalam pembelajaran. Siswa bisa saling bersaing dan dan melihat peringkat mereka secara langsung di papan peringkat. Guru bisa melihat dan memantau prosesnya serta mengunduh hasilnya dalam bentuk excel. Apliasi Quiziz layak digunakan sebagai aplikasi yang mendukung revolusi pembelajaran 4.0. kuis yang dibentuk memiliki banyak pilihan aplikasi quiz, pilihan ganda, kotak centak, isian kosong, pemilihan, open ended dan meluncur. belajar dengan pemanfaatan teknologi dengan aplikasi Quizizz disamping menyenangkan, menantang, dan interaktif akan berkontribusi pada peningkatan kompetensi peserta didik dan kreatifitas pendidik. Pemanfaatan media pembelajaran Quizizz yang mengakomodir kebutuhan pembelajaran bertujuan mencapai tujuan pembelajaran dengan meningkatkan pemahaman dan ketrampilan peserta didik (Aini, 2019).

Powerpoint adalah salah satu software yang dirancang khusus untuk mampu menampilkan program multimedia dengan menarik, relative murah, karena tidak membutuhkan bahan baku selain alat untuk penyimpanan data mudah dalam pembuatan, mudah dalam penggunaannya (Anomeisa \& Ernaningsih, 2020). Powerpoint digunakan dalam sebuah presentasi, memiliki fasilitas-fasilitas untuk membuat multimedia pembelajaran interaktif. Pada powerpoint guru bisa memasukkan suara, teks, gambar bahkan video sekaligus. Halaman atau slide pada powerpoint dirancang khusus dengan dilengkapi tombol-tombol yang akan melibatkan pengguna dalam pengoperasian powerpoint. Siswa dapat mengulang-ulang materi sesuai kehendaknya apabila merasa belum paham. Kemampuan siswa yang beragam akan menjadi terbantu dengan multimedia interaktif. peserta didik lebih mengerti pada materi yang disampaikan guru, peserta didik lebih konsentrasi dan aktif dalam proses pembelajaran, powerpoint memaksimalkan rencana pembelajaran. peserta didik lebih mengerti pada materi yang disampaikan guru, peserta didik lebih konsentrasi dan aktif dalam proses pembelajaran, powerpoint memaksimalkan rencana pembelajaran (Misbahudin et al., 2018). Youtube merupakan jaringan media sosial yang paling banyak diminati masyarakati. Pemanfaatan Youtube sebagai media ajar berperan positif secara signifikan terhadap peningkatan minat belajar (Mujianto, 2019). Youtube juga memiliki peranan positif yang signifikan terhadap peningkatan motivasi belajar (Iqbal et al., 2018). Langkahlangkah pembelajaran FOCQIPOTU adalah

1. Guru membuat daftar kelas dan mengintive siswa dalam Classroom

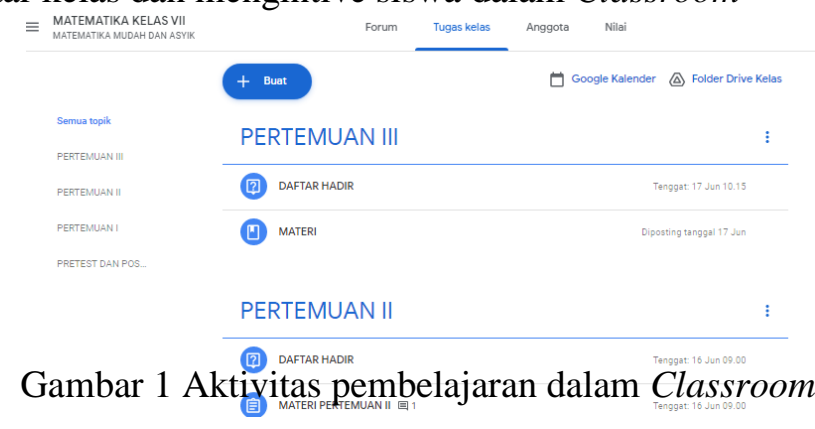


Peningkatan Kualitas Pembelajaran Jarak Jauh (PJJ) Berbasis FOCQIPOTU, Hamzah Sa 'ban Saragih, Risna Mira Bella Saragih, Khoiruddin Matondang

2. Guru membuat materi dalam powerpoint sekaligus membuat video pembelajaran

3. Menambah video pembelajaran dalam akun youtube https://youtu.be/OxjFEsvBOoE

4. Guru membuat alur pembelajaran yang dibuat dalam Google Formulir dan telah disematkan linknya di dalam classwork https://forms.gle/K3EkLnygMYiS2Mht8
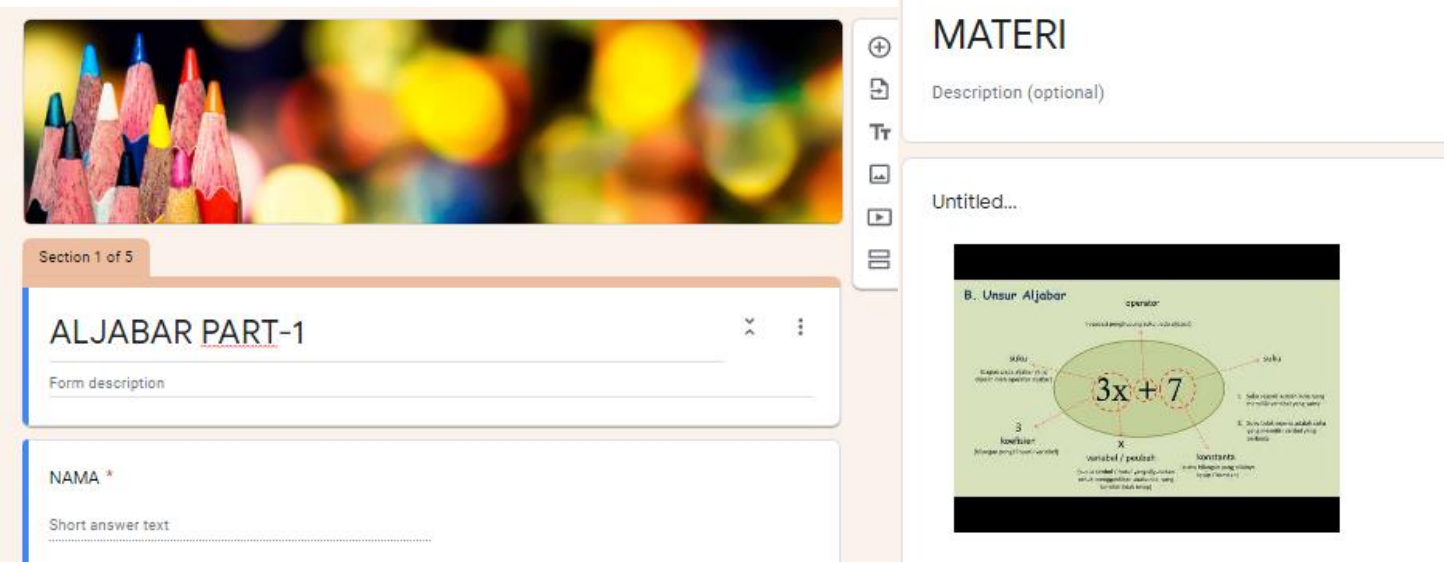

Gambar 2. Alur pembelajaran yang dibuat dalam Google Formulir

5. Membuat latihan soal dalam Quizizz

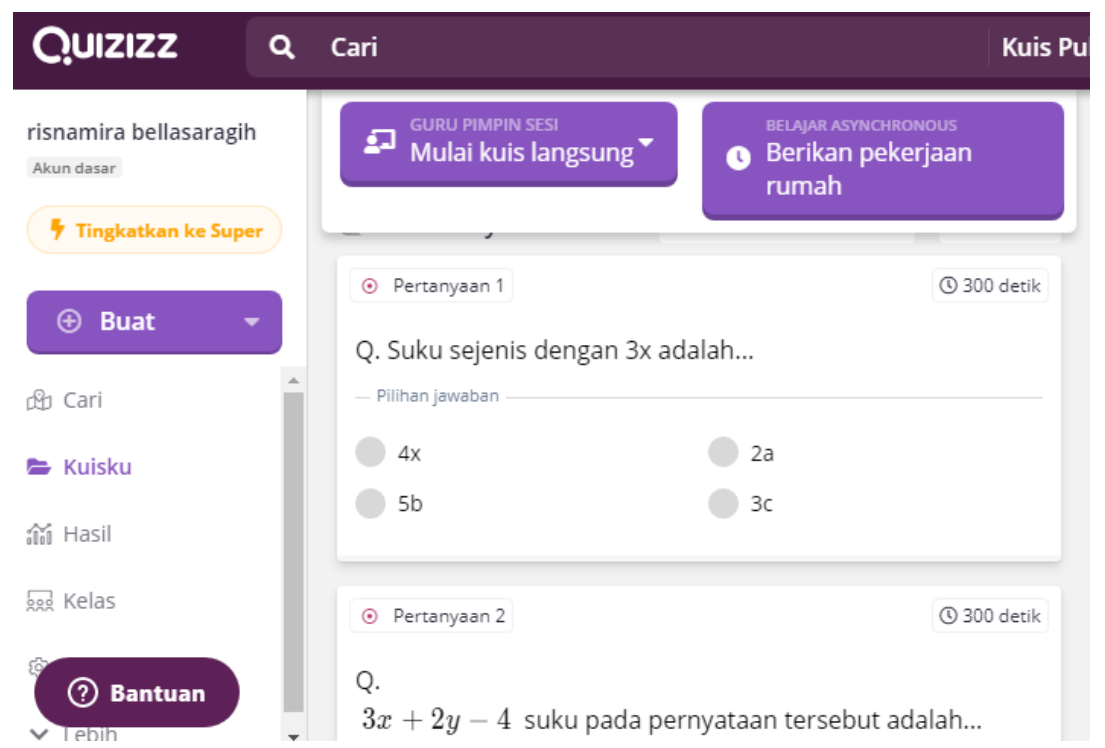

Gambar 3. Latihan dalam Quizizz

Berdasarkan latar belakang dan survei literatur yang telah dijelaskan di atas, tujuan penelitian ini untuk (1) menganalisa apakah FOCQIPOTU dapat meningkatkan kualitas pembelajaran jarak jauh matematika di SMP, (2) bagaimana aktivitas siswa selama pembelajaran menggunakan FOCQIPOTU.

\section{METODE}

Penelitian ini adalah penelitian eksperimen semu (quasi experiment). Rancangan yang digunakan dalam penelitian ini meliputi tiga tahapan, yaitu: (1) Tahap perencanaan, (2) Tahap uji 
coba, (3) Tahap pelaksanaan. Rancangan eksperimen yang digunakan dalam penelitian ini adalah Pretest Posttest Control Group Design. Rancangan eksperiment disajikan pada tabel 1 berikut:

Tabel 1. Rancangan Penelitian

\begin{tabular}{|c|c|c|c|}
\hline Kelas & Pretest & Perlakuan & Postest \\
\hline $\mathbf{A}$ & $\mathrm{T}_{1}$ & $\mathrm{X}$ & $\mathrm{T}_{2}$ \\
\hline B & $\mathrm{T}_{1}$ & $\mathrm{Y}$ & $\mathrm{T}_{2}$ \\
\hline
\end{tabular}

Keterangan: $\quad \mathrm{X}=$ pembelajarn dengan FOCQIPOTU

$\mathrm{Y}=$ pembelajaran konvensional

$\mathrm{T}_{1}=$ Pretest

$\mathrm{T}_{2}=$ Postest

Populasi dalam penelitian ini adalah seluruh siswa Kelas VII SMP IT Indah Medan. Teknik pengambilan sampel kelompok secara acak (cluster random sampling). Terpilih kelas A sebagai kelas pembelajaran FOCQIPOTU dan kelas B sebagai pembelajaran. Sebelum instrumen diujicobakan, dilakukan validasi terhadap perangkat dan instrumen oleh dua orang ahli. Ahli yang dimaksud dalam hal ini adalah validator yang kompeten yang meliputi dosen pendidikan matematika yaitu Dr. Siswadi, M.Pd dan Yumira Simamora, M.Pd. Validasi perangkat difokuskan pada isi, format, bahasa serta kesesuaian karakteristik pendekatan matematika dengan perangkat pembelajaran daring berbasis FOCQIPOTU. Hasil validasi terhadap perangkat pembelajaran daring dapat dilihat pada tabel 2.

Tabel 2. Rangkuman Hasil Validasi Perangkat Pembelajaran FOCQIPOTU

\begin{tabular}{|l|l|c|l|}
\hline No & \multicolumn{1}{|c|}{ Objek yang dinilai } & $\begin{array}{c}\text { Nilai rata-rata } \\
\text { Validator }\end{array}$ & \multicolumn{1}{|c|}{$\begin{array}{c}\text { Tingkat } \\
\text { Validasi }\end{array}$} \\
\hline 1 & Rencana Pelaksanaan Pembelajaran (RPP) daring & 4,5 & Baik \\
\hline 2 & Test Hasil Belajar & 4,25 & Baik \\
\hline Rata-rata & 4,38 & Baik \\
\hline
\end{tabular}

Hasil perhitungan validitas tiap item tes hasil belajar FOCQIPOTU sebagai berikut.

Tabel 3. Hasil Validitas

\begin{tabular}{|c|c|c|}
\hline Nomor soal & & Keterangan \\
\hline Soal nomor 1 &, 984 & Valid \\
\hline Soal nomor 2 &, 965 & Valid \\
\hline Soal nomor 3 &, 993 & Valid \\
\hline Soal nomor 4 &, 980 & Valid \\
\hline Soal nomor 5 &, 736 & Valid \\
\hline
\end{tabular}

Hasil perhitungan reliabilitas tes ujicoba kemampuan pemecahan masalah dalam bentuk uraian sebagai berikut. 
Peningkatan Kualitas Pembelajaran Jarak Jauh (PJJ) Berbasis FOCQIPOTU, Hamzah Sa 'ban Saragih, Risna Mira Bella

Tabel 4. Hasil perhitungan reliabilitas

\begin{tabular}{|r|r|}
\hline \multicolumn{3}{|c|}{ Reliability Statistics } \\
\hline Cronbach's Alpha & N of Items \\
\hline, 964 & 5 \\
\hline
\end{tabular}

Dari tabel di atas diketahui bahwa terdapat 5 soal dengan nilai Cronbach's Alpha 0,964 > 0,60.

Maka kesimpulannya semua soal reliabel atau konsisten.

Tabel 5. Rangkuman Hasil Perhitungan Daya Beda

\begin{tabular}{|c|r|r|r|r|r|}
\hline & Soal 1 & Soal 2 & Soal 3 & Soal 4 & Soal 5 \\
\hline Skor Maks Ideal & 15 & 15 & 15 & 15 & 15 \\
\hline Jumlah Skor Kelompok Atas & 172 & 190 & 173 & 179 & 91 \\
\hline Jumlah Skor Kelompok Bawah & 118 & 142 & 110 & 94 & 40 \\
\hline Indeks & 0,24 & 0,21 & 0,28 & 0,38 & 0,23 \\
\hline Interpretasi & Cukup & Cukup & Cukup & Cukup & Cukup \\
\hline
\end{tabular}

Untuk hasil perhitungan tingkat kesukaran hasil uji coba instrumen, akan disajikan pada tabel berikut:

Tabel 6. Rangkuman Hasil Perhitungan Tingkat Kesukaran

\begin{tabular}{|l|l|l|l|l|l|}
\hline & Butir 1 & Butir 2 & Butir 3 & Butir 4 & Butir 5 \\
\hline Indeks & 0,64 & 0,74 & 0,63 & 0,61 & 0,29 \\
\hline Interpretasi & Sedang & Mudah & Sedang & Sedang & Sukar \\
\hline
\end{tabular}

Data hasil pretest dan postest kelas eksperimen dan kontrol terlihat pada gambar di bawah ini.

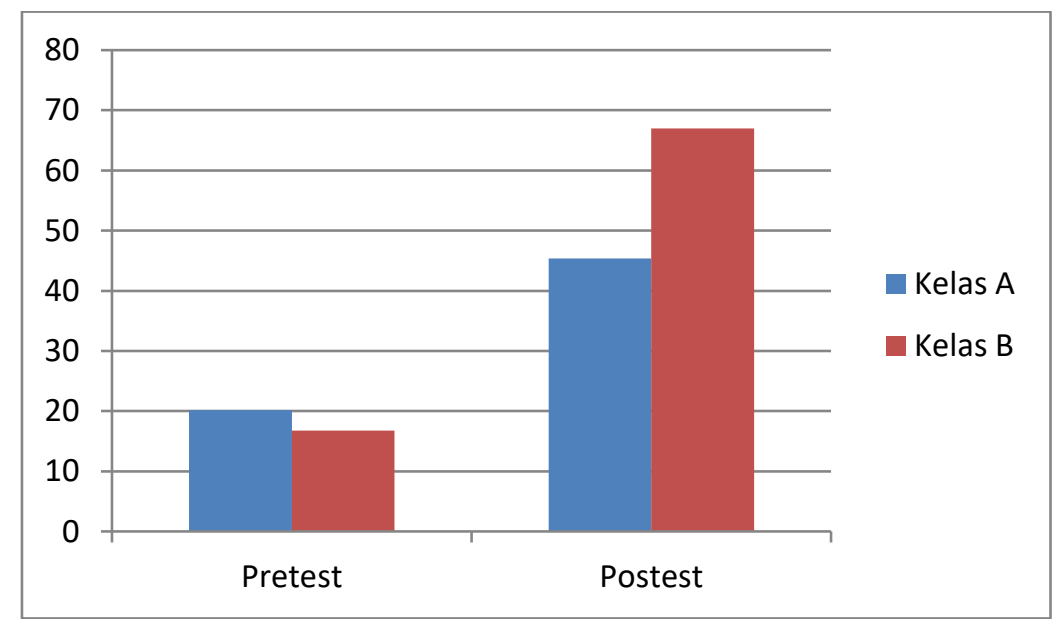

Gambar 4. Data Hasil Pretest dan Postest

Untuk melihat kualitas pembelajaran jarak jauh, analisis data yang dilakukan sebagai menggunakan gain ternormalisasi sebagai berikut:

$$
\text { Indeks Gain }(g)=\frac{\text { Nilai Postes }- \text { Nilai Pretes }}{\text { Nilai Ideal- Nilai Pretes }}
$$


Tabel 7. Kriteria Indeks Gain (g)

\begin{tabular}{|c|c|}
\hline Kriteria & Keterangan \\
\hline$g>0,7$ & Tinggi \\
\hline $0,3<g \leq 0,7$ & Sedang \\
\hline$g \leq 0,7$ & Rendah \\
\hline
\end{tabular}

Sumber : (Hake, 1998)

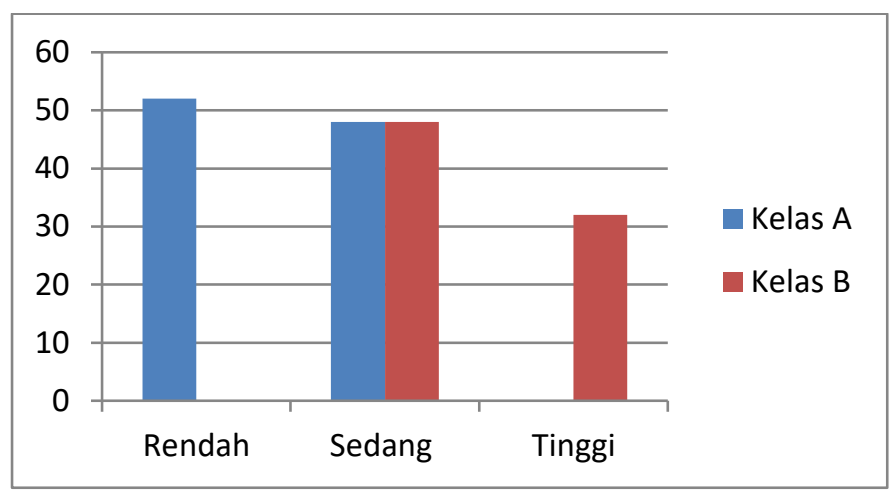

Gambar 5. Data Hasil Gain

Tabel 8. Uji Normalitas Pretest

\begin{tabular}{|l|c|r|r|r|r|r|r|}
\hline \multicolumn{10}{|c|}{ Tests of Normality } \\
\hline & \multirow{2}{*}{ Kelas } & \multicolumn{9}{|c|}{ Kolmogorov-Smirnov ${ }^{\mathrm{a}}$} & \multicolumn{3}{|c|}{ Shapiro-Wilk } \\
\cline { 3 - 9 } & & Statistic & \multicolumn{1}{c|}{ df } & \multicolumn{1}{c|}{ Sig. } & \multicolumn{1}{c|}{ Statistic } & \multicolumn{1}{c|}{ df } & \multicolumn{1}{c}{ Sig. } \\
\hline \multirow{2}{*}{ Nilai } & $\mathrm{A}$ &, 115 & 25 &, $200^{*}$ &, 949 & 25 &, 240 \\
\cline { 2 - 9 } & $\mathrm{B}$ &, 139 & 25 &, $200^{*}$ &, 961 & 25 &, 439 \\
\hline
\end{tabular}

a. Lilliefors Significance Correction

*. This is a lower bound of the true significance.

Tabel 9. Uji Normalitas Postest

\begin{tabular}{|l|c|l|l|l|l|l|l|}
\hline \multicolumn{8}{|c|}{ Tests of Normality } \\
\hline & \multirow{2}{*}{ Kelas } & \multicolumn{4}{|c|}{ Kolmogorov-Smirnov ${ }^{\mathrm{a}}$} & \multicolumn{3}{c|}{ Shapiro-Wilk } \\
\cline { 3 - 9 } & & Statistic & Df & Sig. & Statistic & df & Sig. \\
\hline \multirow{2}{*}{ Nilai } & $\mathrm{A}$ &, 100 & 25 &, $200^{*}$ &, 964 & 25 &, 506 \\
\cline { 2 - 9 } & $\mathrm{B}$ &, 178 & 25 &, 040 &, 930 & 25 &, 087 \\
\hline
\end{tabular}

a. Lilliefors Significance Correction

*. This is a lower bound of the true significance.

Tabel 10. Uji Normalitas Gain

\begin{tabular}{|l|c|r|r|r|r|r|r|}
\hline \multicolumn{9}{|c|}{ Tests of Normality } \\
\hline & \multirow{2}{*}{ Kelas } & \multicolumn{9}{|c|}{ Kolmogorov-Smirnov ${ }^{\mathrm{a}}$} & \multicolumn{3}{|c|}{ Shapiro-Wilk } \\
\cline { 3 - 9 } & & Statistic & Df & Sig. & Statistic & df & Sig. \\
\hline \multirow{2}{*}{ Nilai } & $\mathrm{A}$ &, 119 & 25 &, $200^{*}$ &, 957 & 25 &, 360 \\
\cline { 2 - 8 } & $\mathrm{B}$ &, 128 & 25 &, $200^{*}$ &, 937 & 25 &, 125 \\
\hline
\end{tabular}

a. Lilliefors Significance Correction

*. This is a lower bound of the true significance.

Dari tabel di atas terlihat bahwa nilai signifikansinya lebih dari 0,05. Dengan ini dapat disimpulkan bahwa gain kelas eksperimen dan kontrol berdistribusi normal. 
Peningkatan Kualitas Pembelajaran Jarak Jauh (PJJ) Berbasis FOCQIPOTU, Hamzah Sa 'ban Saragih, Risna Mira Bella Saragih, Khoiruddin Matondang

Tabel 11. Uji Homogenitas Pretest, Postest dan Gain

\begin{tabular}{|c|c|c|c|c|c|}
\hline & \multicolumn{3}{|c|}{ Test of Homogeneity of Variances } & \\
\hline & \multicolumn{3}{|c|}{ Hasil } & Ket \\
\hline Aspek & Levene Statistic & df1 & df2 & Sig. & Homogen \\
&, 097 & 1 & 48 &, 756 & Homogen \\
\hline Pretest &, 178 & 1 & 48 &, 675 & Homogen \\
\hline Postest &, 256 & 1 & 48 &, 615 & .
\end{tabular}

Untuk melihat aktivitas siswa selama pembelajaran menggunakan FOCQIPOTU digunakan lembar observasi. Lembar aktivitas siswa pada pembelajaran FOCQIPOTU sebagai berikut.

Tabel 12. Lembar observasi aktivitas siswa

\begin{tabular}{|l|l|l|l|l|l|l|}
\hline No & \multicolumn{1}{|c|}{ KOMPONEN } & 1 & 2 & 3 & 4 & 5 \\
\hline 1 & Bergabung dalam grup kelas Whatsapp & & & & & \\
\hline 2 & Mengisi absensi tepat waktu pada Classroom & & & & & \\
\hline 3 & Mengklik link pembelajaran di Google Classroom & & & & & \\
\hline 4 & Mengisi identitas dengan lengkap di Google Form & & & & & \\
\hline 5 & Membaca peta konsep di Google Form & & & & & \\
\hline 6 & Membaca kalimat motivasi di Google Form & & & & & \\
\hline 7 & Mengikuti materi pembelajaran di Youtube & & & & \\
\hline 8 & Memberikan komentar di Youtube & & & & & \\
\hline 9 & Bertanya kepada guru & & & & \\
\hline 10 & Mengikuti latihan di Quizizz & & & & \\
\hline
\end{tabular}

\section{HASIL DAN DISKUSI}

Penelitian ini dilaksanakan di SMP IT Indah Medan Penelitian dilaksanakan pada bulan April sampai Juni 2021. Dilaksanakan selama 5 kali. Kegiatan penelitian dan rincian pelaksanaan kegiatan ini dilaksanakan sesuai dengan jadwal pada tabel 13.

Tabel 13. Jadwal Pelaksanaan Penelitian

\begin{tabular}{|l|l|l|l|}
\hline No & \multicolumn{1}{|c|}{ Tanggal } & \multicolumn{1}{|c|}{ Kegiatan } & \multicolumn{1}{c|}{ Materi } \\
\hline 1 & 06 April 2021 & Pelaksanaan Pretest & Pretest \\
\hline 2 & 14 Juni 2021 & Pelaksanaan Pembelajaran 1 & $\begin{array}{l}\text { Bentuk dan unsur-unsur } \\
\text { aljabar }\end{array}$ \\
\hline 3 & 16 Juni 2021 & Pelaksanaan Pembelajaran 2 & $\begin{array}{l}\text { Penjumlahan dan } \\
\text { pengurangan bentuk aljabar }\end{array}$ \\
\hline 4 & 17 Juni 2021 & Pelaksanaan Pembelajaran 3 & $\begin{array}{l}\text { Perkalian dan pembagian } \\
\text { bentuk aljabar }\end{array}$ \\
\hline 5 & 18 Juni 2021 & Pelaksanaan Postest & Postest \\
\hline
\end{tabular}

\section{Uji Independent Samples Test Gain}

Untuk melihat peningkatan kemampuan pemecahan masalah matematika antara siswa yang memperoleh pembelajaran dengan pembelajaran FOCQIPOTU dengan siswa memperoleh pembelajaran dengan pendekatan biasa adalah dengan menghitung gain kedua kelas. Data hasil pengujian gain ternormalisasi dapat dilihat pada tabel berikut :

Perhitungan Uji Independent Samples Test 
Tabel 14. Independent Samples Test

\begin{tabular}{|l|l|r|r|r|c|}
\hline \multicolumn{7}{|c|}{ Group Statistics } \\
\hline \multirow{2}{*}{ Kilai } & Kelas & \multicolumn{1}{|c|}{ N } & \multicolumn{1}{c|}{ Mean } & $\begin{array}{c}\text { Std. } \\
\text { Deviation }\end{array}$ & $\begin{array}{c}\text { Std. Error } \\
\text { Mean }\end{array}$ \\
\cline { 2 - 7 } & Kksperimen & 25 &, 5980 &, 14110 &, 02822 \\
\hline
\end{tabular}

Tabel di atas menunjukkan kedua kelompok mempunyai masing-masing 25 sampel. Nilai kelas Eksperimen lebih tinggi dari Kelas kontrol dilihat dari rata-ratanya 0,6 dengan 0,3.

Tabel 15. Independent Samples Test

\begin{tabular}{|c|c|c|c|c|c|c|c|c|c|c|}
\hline \multicolumn{11}{|c|}{ Independent Samples Test } \\
\hline & & \multicolumn{2}{|c|}{$\begin{array}{c}\text { Levene's } \\
\text { Test for } \\
\text { Equality of } \\
\text { Variances }\end{array}$} & \multicolumn{7}{|c|}{ t-test for Equality of Means } \\
\hline & & \multirow[b]{2}{*}{$\mathbf{F}$} & \multirow[b]{2}{*}{ Sig. } & \multirow[b]{2}{*}{$\mathbf{t}$} & \multirow[b]{2}{*}{ df } & \multirow{2}{*}{$\begin{array}{l}\text { Sig. } \\
(2- \\
\text { tailed })\end{array}$} & \multirow{2}{*}{$\begin{array}{c}\text { Mean } \\
\text { Difference }\end{array}$} & \multirow{2}{*}{$\begin{array}{l}\text { Std. Error } \\
\text { Difference }\end{array}$} & \multicolumn{2}{|c|}{$\begin{array}{c}95 \% \\
\text { Confidence } \\
\text { Interval of the } \\
\text { Difference }\end{array}$} \\
\hline & & & & & & & & & Lower & Upper \\
\hline \multirow[t]{2}{*}{ Nilai } & $\begin{array}{l}\text { Equal } \\
\text { variances } \\
\text { assumed }\end{array}$ & ,256 & 615 & 6,908 & 48 & 000 & ,28920 &, 04187 & ,20502 &, 37338 \\
\hline & $\begin{array}{l}\text { Equal } \\
\text { variances } \\
\text { not } \\
\text { assumed }\end{array}$ & & & 6,908 & 47,603 & ,000 & ,28920 & 04187 & ,20500 & ,37340 \\
\hline
\end{tabular}

Dari tabel di atas, terlihat nilai signifikansi 2 arah (t-tailed) $0.000<0.05$. sehingga hipotesis nol ditolak. Dengan kata lain ada perbedaan peningkatan memahami masalah antara kelas eksperimen dengan kelas kontrol.

\section{Aktivitas Siswa}

Hasil lembar aktivitas sisa dalam pembelajaran FOCQIPOTU bisa terlihat dari tabel berikut.

Tabel 16. Hasil penilaian lembar observasi aktivitas siswa

\begin{tabular}{|c|l|c|c|c|}
\hline No & Kategori Aktivitas pembelajaran & Jumlah Responden & Persentase & Rata-rata \\
\hline 1 & Cukup Baik & 3 & $12 \%$ & 3,30 \\
\hline 2 & Baik & 21 & $84 \%$ & 3,79 \\
\hline 3 & Sangat Baik & 1 & $4 \%$ & 4,5 \\
\hline \multicolumn{2}{|r|}{ Rata-rata } & 3,86 \\
\hline
\end{tabular}

Dari hasil lembar observasi langkah-langkah aktivitas siswa selama pelaksanaan pembelajaran FOCQIPOTU sebagai berikut.

1. Siswa bergabung dalam Whatsapp grup

2. Siswa bergabung dalam Classroom 
Peningkatan Kualitas Pembelajaran Jarak Jauh (PJJ) Berbasis FOCQIPOTU, Hamzah Sa 'ban Saragih, Risna Mira Bella Saragih, Khoiruddin Matondang

103

3. Siswa mengikuti pembelajaran dengan guide Google Form. Diawali dengan mengisi biodata, memahami peta konsep, mencermati kata-kata motivasi

4. Memahami materi melalui youtube

5. Menanyakan hal-hal yang belum diketahui

6. Mengerjakan latihan soal di Quizizz

Berdasarkan hasil uji Independent Samples Test terdapat perbedaan yang signifikan gain hasil belajar siswa yang diajar dengan FOCQIPOTU dengan hasil belajar siswa yang diajar dengan pembelajaran konvensional. Gain kelas FOCQIPOTU kategori sedang sedangkan gain kelas konvensional kategori rendah. Oleh sebab itu bisa diambil kesimpulan bahwa peningkatan kualitas pembelajaran jarak jauh bisa dilakukan dengan FOCQIPOTU.

Komponen google form dalam pembelajaran FOCQIPOTU mencakup alur belajar. Dalam google form terdapat peta konsep dan kata motivasi untuk menumbuhkan semangat belajar siswa.

Unsur lain dalam pembelajaran FOCQIPOTU adalah Quiziziz yang diterapkan dalam latihan soal secara interaktif. Latihan di Quizizz terdiri dari 5 soal terdiri dari pilihan berganda dan isian singkat, dilaksanakan penugasan dan online. Hal tersebut disebabkan pembelajaran menggunakan Quiziz mampu meningkatkan konsentrasi, keaktifan, ketelitian dan ketenangan dalam menyelesaikan latihan (Salsabila et al., 2020). Efektivitas pembelajaran daring bisa dilakukan dengan cara memberikan soal yang menarik, materi diberikan dalam bentuk video yang singkat dengan bahasa yang mudah dipahami siswa (Nugroho et al., 2019). Pendapat tersebut diperkuat oleh (Salsabila et al., 2020)bahwa Quizizz mampu meningkatkan kemampuan siswa dalam memahami soal, siswa menjadi lebih efektif, lebih disiplin dan tepat waktu dalam menyelesaikan tugas yang diberikan.

Materi pembelajaran disampainkan dengan video pembelajaran youtube yang dikemas dengan baik ringkas dan sesuai dengan karakter siswa SMP. Guru dalam pembelajaran FOCQIPOTU berperan sebagai fasilitator dalam membentuk pengetahuan, sehingga kreativiatas guru sangat menentukan. Sebagaimana pernyataan (Wulandari \& Nugroho, 2020)bahwa materi pembelajaran yang ditampilkan melalui video pembelajaran dalam Youtube mampu dipahami dengan baik oleh siswa.

Peningkatan kemampuan komunikasi siswa meningkat melalui penerapan Google Classroom (Rahma et al., 2020). Siswa mampu memahami konsep matematika yang diajarkan serta memudahkan siswa dalam meriview pembelajaran melalui penyajian materi dalam powerpoint (Damayanti \& Qohar, 2019). Guru melakukan negosiasi secara eksplisit, kooperatif, serta penguatan, menghindari perkataan yang kurang baik yang dapat menurunkan rasa percaya diri siswa. Peran guru seperti di atas memberi kesempatan siswa untuk mencari, menemukan dan membangun sendiri pengetahuannya dan bukan hasil dari meniru algoritma yang diberikan guru. 


\section{KESIMPULAN}

Kesimpulan dari penelitian ini adalah FOCQIPOTU dapat meningkatkan kualitas pembelajaran jarak jauh matematika di SMP. Hal ini dapat dilihat dari perbedaan peningkatan gain ternormalisasi yang signifikan antara siswa yang mengikuti pembelajaran FOCQIPOTU dengan siswa yang mengikuti pembelajaran konvensional, nilai signifikansi 2 arah (t-tailed) $0.000<0.05$. Langkahlangkah aktivitas siswa selama pembelajaran menggunakan FOCQIPOTU siswa bergabung dalam whatsapp grup, siswa bergabung dalam Classroom, siswa mengikuti pembelajaran dengan guide Google Form, memahami materi melalui youtube, menanyakan hal-hal yang belum diketahui, mengerjakan latihan soal di Quizizz. Rata-rata kategori aktivitas siswa dalam pembelajaran FOCQIPOTU baik $(3,86)$.

\section{UCAPAN TERIMA KASIH}

Terimakasih kami ucapkan kepada Kementerian Riset dan Teknologi / Badan Riset dan Inovasi Nasional yang telah membiayai penelitian ini melalui program Penelitian Dosen Pemula 2020. Lembaga Layanan Pendidikan Tinggi Wilayah I Sumatera Utara, Rektor, LPPM, Dekan FKIP Univa Medan serta Bapak/Ibu Kepala Sekolah, seluruh guru dan siswa SMP IT indah Medan yang sudah berpartisipasi dalam pelaksanaan penelitian ini.

\section{REFERENSI}

Aini, Y. I. (2019). Pemanfaatan Media Pembelajaran Quizizz Untuk Pembelajaran Jenjang Pendidikan Dasar Dan Menengah Di Bengkulu. Jurnal Kependidikan, 2(25), 1-6.

Anomeisa, A. B., \& Ernaningsih, D. (2020). Interactive learning media using VBA PowerPoint in group data presentation. Jurnal Pendidikan Matematika Raflesia, 05(01), 17-31.

Asyura, I., \& Dewi, R. (2020). Analisis Kemampuan Matematis Mahasiswa PGSD Terhadap Penggunaan Geogebra Classroom di Era dan Pasca Pandemi COVID-19. Jurnal Cendekia: Jurnal Pendidikan Matematika, 4(2), 976-989. https://doi.org/10.31004/cendekia.v4i2.325

Damayanti, P. A., \& Qohar, A. (2019). Pengembangan Media Pembelajaran Matematika Interaktif Berbasis Powerpoint pada Materi Kerucut. Kreano, Jurnal Matematika Kreatif-Inovatif, 10(2), 119-124. https://doi.org/10.15294/kreano.v10i2.16814

Fajriana*, F., \& Safriana, S. (2021). Analisis Kesiapan Guru Fisika dan Matematika dalam Pembelajaran Daring. Jurnal Pendidikan Sains Indonesia, 9(2), 293-304. https://doi.org/10.24815/jpsi.v9i2.19162

Hake, R. R. (1998). Interactive-engagement versus traditional methods: A six-thousand-student survey of mechanics test data for introductory physics courses. American Journal of Physics, 66(1), 64-74. https://doi.org/10.1119/1.18809

Husein, H. (2016). Penggunaan Google Form sebagai alat penilaian kinerja Dosen di Prodi PGMI UNISKA MUHAMMAD ARSYAD AL BANJARI. Jurnal Pendidikan Dasar Islam, 8(1), 40- 
Peningkatan Kualitas Pembelajaran Jarak Jauh (PJJ) Berbasis FOCQIPOTU, Hamzah Sa 'ban Saragih, Risna Mira Bella Saragih, Khoiruddin Matondang

50.

Iqbal, M., Rosramadhana, R., Amal, B. K., \& Rumapea, M. E. (2018). Penggunaan Google Forms Sebagai Media Pemberian Tugas Mata Kuliah Pengantar Ilmu Sosial. Jupiis: Jurnal Pendidikan Ilmu-Ilmu Sosial, 10(1), 120. https://doi.org/10.24114/jupiis.v10i1.9652

Misbahudin, D., Rochman, C., Nasrudin, D., \& Solihati, I. (2018). Penggunaan Power Point Sebagai Media Pembelajaran: Efektifkah? WaPFi (Wahana Pendidikan Fisika), 3(1), 43. https://doi.org/10.17509/wapfi.v3i1.10939

Mujianto, H. (2019). Pemanfaatan Youtube Sebagai Media Ajar Dalam Meningkatkan Minat Dan Motivasi Belajar. Jurnal Komunikasi Hasil Pemikiran Dan Penelitian, 5(1), 135-159. www.journal.uniga.ac.id

Nugroho, K. U. Z., Widada, W., Zamzaili, \& Herawaty, D. (2019). Pemahaman Konsep Matematika melalui Media Youtube dengan Pendekatan Etnomatematika. Jurnal Pendidikan Matematika Raflesia, 04(01), 96-106. https://ejournal.unib.ac.id/index.php/jpmr\%0APemahaman

Prabowo, A. S., Conia, P. D. D., Afiati, E., Handoyo, A. W. R., Muhibah, S., Rochani, Sholih, Khairun, D. Y., Dalimunthe, R. Z., Wibowo, B. Y., \& Nurmala, M. D. (2020). Kesiapan Guru Dalam MelaksanaPrabowo, A. S., Conia, P. D. D., Afiati, E., Handoyo, A. W. R., Muhibah, S., Rochani, Sholih, Khairun, D. Y., Dalimunthe, R. Z., Wibowo, B. Y., \& Nurmala, M. D. (2020). Kesiapan Guru Dalam Melaksanakan Pembelajaran Daring Dite. Jurnal Penelitian Bimbingan Dan Konseling, 5(2), 9-12.

Purba, L. S. L. (2019). Peningkatan Konsentrasi Belajar Mahasiswa Melalui Pemanfaatan Evaluasi Pembelajaran Quizizz Pada Mata Kuliah Kimia Fisika I. Jurnal Dinamika Pendidikan, 12(1), 29. https://doi.org/10.33541/jdp.v12i1.1028

Purwati, D., \& Nugroho, A. N. P. (2018). Pengembangan Media Evaluasi Pembelajaran Sejarah Berbasis Google Formulir Di Sma N 1 Prambanan. ISTORIA: Jurnal Pendidikan Dan Ilmu Sejarah, 14(1). https://doi.org/10.21831/istoria.v14i1.19398

Rahma, N. A., Rochayati, M. Y., \& Muniri, M. (2020). Pengaruh Model Pembelajaran Think Pair Share Menggunakan Media Google Classroom terhadap Kemampuan Komunikasi Matematis Mahasiswa IAIN Tulungagung. Jurnal Tadris Matematika, 3(2), 195-206. https://doi.org/10.21274/jtm.2020.3.2.195-206

Salsabila, U. H., Habiba, I. S., Amanah, I. L., Istiqomah, N. A., \& Difany, S. (2020). Pemanfaatan Aplikasi Quizizz Sebagai Media Pembelajaran Ditengah Pandemi Pada Siswa SMA. Jurnal Ilmiah Ilmu Terapan Universitas Jambi|JIITUJ|, 4(2), 163-173. https://doi.org/10.22437/jiituj.v4i2.11605

Santoso, E., Sugandi, M. K., Warmi, A., \& Adirakasiwi, A. G. (2020). Mempersiapkan Calon Guru Matematika Dan Ipa Dalam Menghadapi Era Industri 4.0. BIO EDUCATIO: (The Journal of Science and Biology Education), 5(2), 3-8. https://doi.org/10.31949/be.v5i2.2607

Soni, Hafid, A., Hayami, R., Fatma, Y., Wenando, F. A., Amien, J. Al, Fuad, E., Unik, M., Mukhtar, 
H., \& Hasanuddin. (2018). Optimalisasi Pemanfaatan Google Classroom Sebagai Media Pembelajaran Di SMK Negeri 1 Bangkinang. Jurnal Pengabdian Untuk Mu NegeRI, 2(1), 1-4. https://ejurnal.umri.ac.id/index.php/PengabdianUMRI/article/view/361

Sudarman, S., Sartika, S., Sugiharta, I., \& Farida, F. (2021). Pengaruh E-Learning Berbantuan Google Classroom Terhadap Kemampuan Pemecahan Masalah Matematis. Jurnal Cendekia: Jurnal Pendidikan Matematika, 5(3), 2133-2140. https://doi.org/10.31004/cendekia.v5i3.625

Utami, Y. P., \& Cahyono, D. A. D. (2020). Study At Home: Analisis Kesulitan Belajar Matematika Pada Proses Pembelajaran Daring. Jurnal Ilmiah Matematika Realistik, 1(1), 20-26. https://doi.org/10.33365/ji-mr.v1i1.252

Wulandari, E., \& Nugroho, W. (2020). Sikap Siswa terhadap Video Pembelajaran Jarak Jauh Materi Statistika pada Media Sosial Youtube. Edumatica: Jurnal Pendidikan Matematika, 10(2), 1-9. https://online-journal.unja.ac.id/edumatica/article/view/10584

Yustika, G. P., Subagyo, A., \& Iswati, S. (2019). Masalah Yang Dihadapi Dunia Pendidikan Dengan Tutorial Online: Sebuah Short Review. Tadbir : Jurnal Studi Manajemen Pendidikan, 3(2), 187. https://doi.org/10.29240/jsmp.v3i2.1178. 